\title{
SHOULD THE NEW ZEALAND PARLIAMENT ALLOW THE INTELLECTUAL PROPERTY OFFICE OF NEW ZEALAND TO CONTINUE TO GRANT PATENTS FOR ISOLATED HUMAN GENES?
}

\author{
Ruth Upperton*
}

\begin{abstract}
It is time for New Zealanders to decide whether we want to allow patents over isolated human genes. In making this decision, we should take heed of the pitfalls other jurisdictions have encountered in this area. In this article, I determine the approach New Zealand intellectual property law should take to the patenting of isolated human genes, with reference to the arguments and issues raised by the Myriad Genetics litigation in the United States of America. I conclude that a nuanced approach should be adopted. Isolated human genes are not patentable subject-matter from a legal perspective; however, patents in the field of gene therapeutics should be allowed on policy grounds.
\end{abstract}

\section{INTRODUCTION}

The good patent gives the world something it did not truly have before, whereas the bad patent has the effect of trying to take away from the world something which it effectively already had. ${ }^{1}$

In each cell of each human body, and in the cells of almost all other living things on Earth, we find deoxyribonucleic acid, or DNA. ${ }^{2}$ DNA is a large molecule consisting of two strands of covalently bonded nucleotides, held together in a double helix structure by the weaker hydrogen

\footnotetext{
* Article submitted as part of the LLB(Hons) programme at Victoria University of Wellington. The author would like to thank Professor Susy Frankel for her attentive supervision.

1 Paul Cole (ed) CIPA Guide to the Patents Act (7th ed, Sweet \& Maxwell, London, 2011) at 83.

2 Richard R Sinden DNA Structure and Function (Academic Press, San Diego, 1994) at 1.
} 
bonds between the strands. ${ }^{3}$ Each nucleotide contains a nucleobase, and every three nucleobases code for an amino acid. A string of amino acids make up a protein, and proteins make up the human body. ${ }^{4}$ A sequence of amino acids that codes for a particular characteristic of the human body is called a gene. ${ }^{5}$ Scientists can isolate a gene from the rest of a person's DNA, so it exists as a single strand of nucleotides, with its covalent bonds broken at either end. ${ }^{6}$ Gene isolation was originally a complex procedure, but today is mostly automated and can be done quickly. ${ }^{7}$ The Intellectual Property Office of New Zealand (IPONZ) has granted patents for isolated human genes. ${ }^{8}$ However, IPONZ has not released any guidelines on how it approaches patent claims for any kind of genetic material, and there has been no case law on the question of whether IPONZ should be granting these patents or not.

We in New Zealand are in a unique position to decide whether or not we want to allow patents over isolated human genes, as our current patent system does not fully examine patents before granting them, making all patents conditional on later decisions. ${ }^{9}$ The United States biotechnology sector is much more advanced than ours, and the United States' patent system has proved destructive in that sector, driving up the cost of diagnosis and inhibiting research. We need to learn from their example and establish a law of gene patenting that encourages innovation, ensures access to healthcare, and is consistent with our patenting law as a whole.

In this article I aim to determine the approach New Zealand intellectual property law should take to the patenting of isolated human genes. I will first analyse the New Zealand law on patentable subject matter, and then the tests United States' courts have used to determine the patentability of isolated genes, as there is no New Zealand case law on this specific issue. I will then decide which test is best for New Zealand and how it would apply to isolated human genes.

I will then examine further legal issues in this field: the impact of the Agreement on TradeRelated Aspects of Intellectual Property Rights (TRIPS), and the Patent Act 1953's morality exemptions, as well as the related exemption from patentability for methods of medical treatment and diagnosis practiced on humans.

3 At $1-2$

4 At $1-3$.

5 At $1-3$.

6 Peter B Kaufman Gene Biotechnology (3rd ed, CRF Press, Florida, 2011) at 17.

7 At 17.

8 See for example Myriad Genetics "MTS gene, mutations therein, and methods for diagnosing cancer using MTS gene sequence" NZ Patent 283539, filed 17 March 1995, registered 12 June 1998; and Myriad Genetics "Germline mutations in the MTS gene and method for detecting predisposition to cancer at the MTS gene" NZ Patent 284612, filed 17 March 1995, registered 23 January 1998.

9 Susy Frankel Intellectual Property Law in New Zealand (2nd ed, LexisNexis, Wellington, 2011) at 394. 
Having examined the legal issues, I will then consider policy. Does patenting in the field of biotechnology inhibit or encourage research? Do gene patents drive up the costs of genetic tests? I will also attempt an overview of Māori objections to gene patents as voiced in the Wai 262 report, ${ }^{10}$ bearing in mind that Māori objections to intellectual property law are much broader than the scope of this article.

My conclusion is that isolated human genes are not patentable subject matter on the best analysis of patent law, as they are not inventions. The current approach of IPONZ is inappropriate and Parliament needs to intervene to limit the scope of patentability in this area. However, in the field of gene therapeutics, profits from patents are necessary to fund expensive research and development. Parliament should take a nuanced approach that allows gene patenting where it is needed and not where it is harmful.

\section{LEGAL ISSUES: INVENTIONS, TRIPS, MORALITY EXEMPTIONS AND THE METHODS OF MEDICAL DIAGNOSIS EXEMPTION}

\section{A Are Isolated Genes Discoveries or Patentable Inventions?}

\section{New Zealand patent law on inventions}

Patent law aims to provide an incentive for scientific development by granting inventors a 20year monopoly on the exploitation of a patented invention. ${ }^{11}$ The strong monopoly a patent grants is justified because it encourages innovation and rewards inventors for their creativity and hard work. ${ }^{12}$ This ideological basis for patent law is reflected in statute; for subject matter to be validly patented in New Zealand, it must be an invention, not a discovery. ${ }^{13}$ An invention means: ${ }^{14}$

Any manner of new manufacture the subject of letters patent and grant of privilege within section 6 of the Statute of Monopolies and any new method or process of testing applicable to the improvement or control of manufacture; and includes an alleged invention.

Section 6 of the Statute of Monopolies excludes from patentability subject matter that is "contrary to the law... mischievous to the state by raising prices of commodities at home, or hurt of trade, or generally inconvenient". 15 Section 6 must not be applied literally, but must be applied

10 Waitangi Tribunal Ko Aotearoa Tēnei: A Report into Claims Concerning New Zealand Law and Policy Affecting Māori Culture and Identity (Wai 262, 2011) [Wai 262 (Volume 1)].

11 Frankel, above n 9, at 391-392.

12 At 391

13 Patents Act 1953, ss 2 and 7(1).

14 Section 2(1).

15 Statute of Monopolies 1623 (UK), s 6 
"according to the principles which have been developed" for its application. ${ }^{16}$ One principle is that an invention must be "an artificially created state of affairs". ${ }^{17}$ It would be incorrect to patent "natural phenomena, which involve insufficient human involvement or newness to possess the artificiality required of inventions". ${ }^{18}$ A "mere scintilla" of inventive faculty is sufficient to differentiate a discovery from an invention. ${ }^{19}$

IPONZ considers whether the subject matter is an invention or is novel before granting the patent. IPONZ does not however, examine the claim for obviousness, lack of inventive step or lack of usefulness, which are instead grounds for revocation or third-party opposition. ${ }^{20}$

A main issue in the field of gene patenting, therefore, is whether an isolated human gene can be considered an invention, or whether isolating a gene is merely to discover what is already present in nature. IPONZ has granted patents over isolated human genes, clearly thinking that they satisfy the above test of invention. ${ }^{21}$ However, it is my opinion that the approach taken by IPONZ is incorrect. It is more consistent with New Zealand patent law to find that isolated human genes are not inventions. There has been no parliamentary or judicial debate on this issue in New Zealand, so I turn to the United States judicial debate to consider arguments for and against finding that an isolated gene is an invention.

\section{United States' patent law on inventions}

Under United States law, an invention is patentable if it is novel, non-obvious, has utility and is appropriate subject-matter for a patent. ${ }^{22}$ Judges have found that implicit in the statutory scheme is an exemption from patent-eligibility for products of nature, laws of nature, and abstract ideas. ${ }^{23}$ The

16 National Research Development Corporation v Commissioner of Patents (1959) 102 CLR 252 (HCA) at 269.

17 At 275, citing Re Lenard's Application (1954) 71 RPC 190 (HCA) at 192.

18 Ben McEniery "Are Plots Patentable?" (2009) 33 MULR 292 at 302

19 Maunder v Wanganui Sash and Door Factory and Timber Co Ltd [1928] NZLR 566 (CA) at 581.

20 Patents Act, ss 21 and 41. See also Frankel, above n 9, at 394.

21 See for example: Myriad Genetics "MTS gene, mutations therein, and methods for diagnosing cancer using MTS gene sequence" NZ Patent 283539, filed 17 March 1995, registered 12 June 1998; and Myriad Genetics "Germline mutations in the MTS gene and method for detecting predisposition to cancer at the MTS gene" NZ Patent 284612, filed 17 March 1995, registered 23 January 1998.

22 Patents 35 USC $\S \S 101-103$.

2335 USC § 101; Diamond v Chakrabatry 447 US 303 (1980); and Bilski v Kappos 561 US 8 (2010). 
challenge to isolated genes as patent-eligible subject matter is therefore that they are products of nature. $^{24}$

The question of the patent-eligibility of isolated human genes arose in the case of Association for Molecular Pathology v United States Patent and Trademark Office, known as the Myriad case. Myriad Genetics is a Utah-based molecular diagnostics company that in 1994 sequenced the BRCA1 gene, a human gene linked to hereditary breast and ovarian cancer. The company then filed a patent for BRCA1, and later BRCA2, another gene with the same link to hereditary cancer. These claims for patents were challenged at the United States' District Court in the Southern District of New York, where they were ruled invalid by Judge Sweet. ${ }^{25}$ The decision was appealed to the United States' Court of Appeals for the Federal Circuit, where two judges, Lourie J and Moore J, overturned Judge Sweet's decision, Bryson J dissenting. ${ }^{26}$ The United States' Supreme Court then remitted the case to the Federal Circuit of Appeals, instructing the Circuit to reconsider in light of the decision of Mayo Collaborative Services v Prometheus Laboratories. ${ }^{27}$ The Federal Circuit Court reaffirmed its decision to allow the gene patents, Bryson $\mathrm{J}$ again dissenting. ${ }^{28}$ In November 2012, the United States' Supreme Court agreed to reconsider the question of whether human genes are patentable. ${ }^{29}$ The Court's decision is expected in 2013.

One of the legal issues in the Myriad cases was whether an isolated gene was a product of nature, or a patent-eligible invention. ${ }^{30}$ The judges in the Myriad cases looked to Diamond $v$ Chakrabatry to solve this issue. In that case, the United States' Supreme Court allowed a patent on a bacterium created in a laboratory because the bacterium had "markedly different characteristics from any found in nature", and was "not nature's handiwork, but [the inventor's] own". ${ }^{31}$ In the Myriad case, both the District Court and court at the Federal Circuit applied the markedly different test. At the District Court, Judge Sweet looked for a key similarity between the native and the

24 Diamond v Chakrabatry, above n 23; Funk Brothers Seed Co v Kalo Inoculant Co 333 US 127 (1948); Parke-Davis \& Co v HK Mulford Co 189 F 95 (Fed Cir 1911); Association for Molecular Pathology $v$ United States Patent and Trademark Office 702 F Supp 2d 181 (SD NY 2010) [Myriad 1]; Association for Molecular Pathology v United States Patent and Trademark Office 653 F 3d 1329 (Fed Cir 2011) [Myriad 2]; and Mayo Collaborative Services v Prometheus Laboratories 132 US 1289 (2012).

25 Myriad 1, above n 24.

26 Myriad 2, above n 24.

27 Mayo v Prometheus, above n 24.

28 Association for Molecular Pathology v United States Patent and Trademark Office No 2010-1406 (Fed Cir August 16, 2012) [Myriad 3].

29 Association for Molecular Pathology v United States Patent and Trademark Office 133 S Ct 694 (2012) at 695.

3035 USC $\$ 101$.

31 Diamond v Chakrabatry, above n 23, at 310. 
isolated gene. He found that they did share a key similarity: they both contained the same genetic code made up of the same sequences of nucleobases. ${ }^{32}$ The isolated gene was thus not markedly different from the native gene, and not patent-eligible. The United States' Supreme Court had previously refused a claim to patent a mixture of nitrogen-fixing bacterial strains, because the claim was over bacteria behaving as they ordinarily would in nature. ${ }^{33}$ Judge Sweet considered that case analogous; the quality of the isolated gene, that of containing a specific genetic code, was a quality found in nature, not created by the inventor. ${ }^{34}$ The gene was behaving with the same characteristics as it had in nature.

At the Federal Circuit, the majority (Lourie and Moore JJ) took a different approach, considering whether there was a key difference between native and isolated DNA. They found that there was. ${ }^{35}$ The minority judge (Bryson J) considered the differences between a native and an isolated gene to be "necessarily incidental to ... extraction" and decided that there was no key difference between the two. ${ }^{36}$

The plaintiffs in Myriad proposed a "magic microscope" test. If it is possible to "zoom in" on the claimed patent as it exists in nature, it is a product of nature and not patentable. ${ }^{37}$ This test was not accepted by the appeal court. ${ }^{38}$

The United States' Supreme Court laid down another relevant test in Mayo Collaborative Services $v$ Prometheus Laboratories, deciding that an inventor cannot claim a method patent in an application of a law of nature. However, an inventor can claim a method patent if he or she adds something to the application of a law of nature, which makes that application inventive. ${ }^{39}$

\section{Which test is best?}

The Myriad Genetics and Prometheus decisions offer four different tests to determine whether subject matter is patentable: the magic microscope test, ${ }^{40}$ the markedly different (looking for a key

32 Myriad 1, above n 24, at 135.

33 Funk Brothers, above n 24.

34 Myriad 1, above n 24, at 108-109.

35 Myriad 2, above n 24, at 41 per Lourie J, and at 15-17 per Moore J; Myriad 3, above n 28, at 42 per Lourie $\mathrm{J}$

36 Myriad 2, above n 24, at 6.

37 At 38-39 per Lourie J.

38 At 45-46 per Lourie J, and at 22-24 per Moore J.

39 Mayo v Prometheus, above n 24, at 11.

40 Myriad 2, above n 24, at 38-39 per Lourie J. 
similarity) test, ${ }^{41}$ the markedly different (looking for a key difference) test, ${ }^{42}$ and the Prometheus laws of nature test. ${ }^{43}$ The Prometheus test and markedly different tests are compatible and could be applied together by considering whether a claimed invention is markedly different from the laws of nature it is based on.

Lourie $\mathbf{J}$ dismissed the magic microscope test, saying that there is a difference between the knowledge of something in nature (knowledge of a genetic sequence in native DNA) and possessing that thing in concrete form (isolating that gene from the rest of the chromosome). ${ }^{44}$ This reasoning is faulty, however, as the possession of something found in nature does not render that thing patentable. To use an analogy, knowing that a new plant species grows in a remote area of the Amazon rainforest is not the same as possessing a plant of that species. It might be very difficult and require a lot of ingenuity to locate and remove one of these plants. But that does not make the plant patentable once it is possessed. There must be a difference between the thing found in nature and the subject matter of the patent.

Moore J's objections to the magic microscope test are more persuasive. The magic microscope test is inconsistent with Funk Brothers Seed Co v Kalo Inoculant Co, ${ }^{45}$ as the combination of bacterial strains in that case could not be found in nature, but were still ruled unpatentable as the strains acted as they would in nature - the inventor was merely taking advantage of traits that the bacteria naturally had. Moore $\mathbf{J}$ further noted that the magic microscope test would not help the plaintiffs who had argued for it. It is impossible, she decided, to zoom in on an isolated gene in nature, as native DNA has a different chemical structure to an isolated strand of DNA. ${ }^{46}$ However, Moore $\mathrm{J}$ applied a very inflexible form of the magic microscope test. Arguably, the test would render isolated genes unpatentable, as the sequence of nucleobases that make up an isolated gene can be found in nature. This difference in opinion, however, illustrates the difficulties inherent in the magic microscope test. The test does not clarify how different the subject matter of a patent has to be from the thing found in nature. Furthermore, the test focuses on the physical and chemical aspects of a thing; whether it actually exists in nature, in the chemical and physical form that is the subject of the claimed patent. It lacks the flexibility of the Chakrabatry markedly different test, which allows a consideration of which aspects of the subject matter are most important. One minor chemical difference may make subject matter patentable under the magic microscope test, regardless

41 Myriad 1, above n 24, at 135.

42 Myriad 2, above n 24, at 41 per Lourie J, and at 15-17 per Moore J; Myriad 3, above n 28, at 42 per Lourie $\mathrm{J}$.

43 Mayo v Prometheus, above n 24, at 11.

44 Myriad 2, above n 24, at 45-46.

45 Funk Brothers, above n 24.

46 Myriad 2, above n 24, at 22-24. 
of whether that difference is relevant to the patent. The majority upon appeal was correct to reject the magic microscope test.

New Zealand courts could adopt either Judge Sweet's key similarity or Lourie and Moore JJ's key difference test, both of which are permutations of the Chakrabatry markedly different test. A New Zealand court is more likely to adopt the key difference test. Looking for a key similarity to declare the subject matter unpatentable would not be consistent with case law that requires a "mere scintilla" of inventiveness to make a product a "manner of new manufacture", and thus patentable. ${ }^{47}$ As long as a genetic product has a key difference that distinguishes it from its natural origins, it should be patentable in New Zealand, subject of course to challenge on the grounds of obviousness, lack of inventive step, ${ }^{48}$ or lack of usefulness. ${ }^{49}$ Judge Sweet's approach of looking for a key similarity could lead to absurd results. Bryson $\mathbf{J}$ uses an example of a baseball bat to show that sometimes something can be extracted from nature, as a baseball bat is from a tree, and be patentable. ${ }^{50}$ Applying Judge Sweet's test, arguably a baseball bat would not be patentable, as it is made from wood. That is a key characteristic shared by both tree and bat. A key similarity between the subject matter and its natural origin should not override any key differences between the two that might render the subject matter patentable. It is best to adopt the approach the majority judges took on appeal.

This approach can be combined with the Prometheus test. A court would consider whether the claimed invention adds enough to the relevant law or product of nature to make the invention markedly different in some key way from its natural origins.

\section{How does the markedly different test apply to isolated genes?}

Lourie $\mathbf{J}$ concluded that an isolated gene is patentable using the markedly different test. The native BRCA gene covalently bonds with the nucleotides to either side of it. ${ }^{51}$ It is part of a chromosome. When a scientist isolates the gene, he or she breaks those covalent bonds. There is a chemical difference between an isolated gene and that gene in nature, because the gene in nature is part of a larger molecule, while an isolated gene is not. Lourie $\mathrm{J}$ distinguished the isolation of a gene from the purification of adrenalin in Parke-Davis \& Co v HK Mulford Co, saying that an isolated gene is chemically different to a gene in a chromosome, unlike adrenalin, which when purified turns from adrenalin in an impure state to adrenalin in a pure state. ${ }^{52}$

47 Maunder v Wanganui Sash and Door, above n 19, at 581; Patents Act, s 2.

48 Patents Act, s 21(1)(e) and s 41(1)(f).

49 Section $41(\mathrm{~g})$.

50 Myriad 2, above n 24, at 22-24.

51 Myriad 2, above n 24, at 41-48; and Myriad 3, above n 28, at 45.

52 Parke-Davis, above n 24; and Myriad 2, above n 24, at 42-44. 
However, Lourie's application of the markedly different test has several flaws. As Bryson J points out in his dissenting judgment, native lithium is covalently bonded to native salts in nature. These covalent bonds are severed when lithium is extracted from the ground - but Lourie $\mathbf{J}$ would not allow a patent in lithium. Furthermore, the limits of a gene are defined by the gene itself, not by the scientists who isolate it. Isolating a gene is analogous to pulling a leaf off a tree. ${ }^{53}$ Nature has defined the line between leaf and tree, and the leaf is unpatentable even if removed from the tree. Nature has likewise defined the line between one gene and the next. The person isolating the gene does not choose where to sever the covalent bonds; that location is determined by where the DNA stops coding for one protein and starts coding for another, or where an intron ends and an exon begins.

A deeper problem with Lourie J's analysis is that he treats DNA as a chemical rather than a way of storing biological information. ${ }^{54}$ Scientifically speaking, it is both: it is a nucleic acid which contains genetic information. If it is treated as a chemical, an isolated gene is patentable, because there are chemical differences between native and isolated DNA. However, DNA should be treated as a way of storing biological information, not as a chemical. It contains genetic information as its main function. Unlike other chemicals, it is not of scientific interest because of how it reacts, but because of the information it contains. As Judge Sweet notes in his judgment, Myriad Genetics' use of isolated genes is predicated on the isolated genes' correspondence to those genes in nature. ${ }^{55}$ The chemical differences discussed by the majority on appeal did not even appear in the patent claims. ${ }^{56}$ Myriad Genetics cannot consistently argue that the key difference between the isolated and native DNA is chemical, when it focuses so unremittingly on DNA's informational aspects.

Lourie J's misapplication of the test is also illustrated by his treatment of the Prometheus case. In considering the effect of the Prometheus decision on the Myriad case, he decided that isolated DNA is a composition of matter, not a law of nature, noting that the genes were "the products of man, albeit following, as all materials do, laws of nature". ${ }^{57}$ However, the correct application of Prometheus is not to see the isolated genes as a law or product of nature, but the native genes as a law or product of nature. In Prometheus, the method used was routine and did not add enough to the law of nature involved to be an invention. ${ }^{58}$ The law of nature at issue in the Myriad case is the informational content of the genes. In the case of isolated genes, the gene is a product of nature, and current methods of extraction are routine, so the final product is not an invention.

53 Myriad 2, above n 24, at 10 per Bryson J dissenting.

54 At 41-48; and Myriad 3, above n 28, at 45.

55 Myriad 1, above n 24, at 131-132.

56 Myriad 3, above n 28, at 16 per Bryson J dissenting.

57 Myriad 3, above n 28, at 51.

58 Mayo v Prometheus, above n 24. 
In applying the markedly different test, Moore $\mathbf{J}$ focused instead on the difference in function between a native and an isolated gene. ${ }^{59}$ Moore $\mathrm{J}$ considered patentable short strands of DNA that did not make up a whole gene. These strands, mostly around 15 nucleotides long, were patentable because the inventor has: 60

...defin[ed] the parts to be retained and discarded ... the result is a product with a function (primer or probe) that is entirely different from the full gene from which it was obtained.

Moore $\mathrm{J}$ considered longer strands comprising most or all of a gene to be patentable, but because of the weight of United States' precedent, not because these claims satisfied a test of patentability. ${ }^{61}$ Her analysis is correct. Nature has not defined the start and end of each probe or primer; that has been done by scientists. However, nature has defined the start and end of each gene. Allowing researchers to patent small segments of a gene could be problematic, as the patents could add up to what is in effect a whole-gene patent. Furthermore, allowing patents on small DNA segments could be harmful for policy reasons, discussed from Part III of this article. However, they are patentable under the markedly different test, while whole genes are not.

While Lourie $\mathrm{J}$ chose the best test, he applied it wrongly. There is a chemical difference between native and isolated DNA, but this difference is not marked enough to satisfy the test. An isolated gene is best considered a discovery, not an invention.

\section{B The Agreement on Trade-Related Aspects of Intellectual Property Rights}

Looking at the United States' law is very helpful in determining what the law should be in New Zealand. However, New Zealand patenting law is subject to a number of limitations that determine how far reform in the gene patenting area can go. These limitations include the provisions of the Agreement on Trade-Related Aspects of Intellectual Property Rights (TRIPS), and New Zealand's current patent law system, particularly the morality exemption and the rule that methods of medical treatment and diagnosis of humans are unpatentable subject matter.

The TRIPS agreement regulates the minimum requirements for intellectual property regimes of member states. Article 27.1 states that patents must be available for inventions in all fields of technology. However, members may make exemptions for inventions that interfere with morality or ordre public, as well as diagnostic, therapeutic and surgical methods for the treatment of humans or animals, plants and animals other than micro-organisms, and biological processes for the production

59 Myriad 2, above n 24, at 15-17.

60 At 17.

61 At 17-19. 
of plants and animals. ${ }^{62}$ Article 8 states that members may take measures to protect public health, to promote technological development, and to prevent the abuse of intellectual property rights by right holders.

If the New Zealand Parliament clarified that isolated genes are not inventions, that legislation would still be compliant with Article 27.1, as patents must be available only for inventions. Furthermore, even if isolated genes amount to an invention, Parliament could restrict the use of gene patents by extending the exemption for methods of medical diagnosis and treatment. This legislation would comply with TRIPS, coming under the Art 27.3(a) exemption for methods of treatment of humans or animals. TRIPS is therefore unlikely to limit reform in the area of gene patents.

\section{Morality Exemptions and the Exemption for Methods of Medical Treatment and Diagnosis}

New Zealand's patent law includes consideration of the morality of the alleged invention. The Commissioner of Patents may refuse a patent application where the use of the invention would be contrary to morality. ${ }^{63}$ However, the contrary to morality provision only allows the Commissioner to analyse whether the use of the invention is immoral, so it is unlikely to apply to gene patents. ${ }^{64} \mathrm{It}$ is potentially immoral to use a patent to overcharge for healthcare or inhibit research; it is not immoral to use biotechnology to improve a person's health.

Issues of morality and policy also arise under $\mathrm{s} 2$ of the Patents Act, which states that the subject matter of a claim is only patentable if it is compatible with s 6 of the Statute of Monopolies Act. ${ }^{65}$ Section 6 of the Statute of Monopolies could conceivably limit the patentability of isolated human genes. Granting these patents could be "generally inconvenient" or "rais[e] prices of commodities at home" because the patents grant a monopoly to companies that can increase healthcare costs and inconvenience researchers and patients. Section 6 brings policy arguments, which I will address in Part III, into the debate over whether allowing gene patents is consistent with New Zealand law.

The exemption from patentability most relevant to gene patents that has arisen from s 6 is the exemption for methods of medical treatment and diagnosis of humans. ${ }^{66}$ Patents in this area are considered generally inconvenient as "the art of the physician or the surgeon in alleviating human

62 Marrakesh Agreement Establishing the World Trade Organisation 1867 UNTS 3, annex 1C (Agreement on Trade-Related Aspects of Intellectual Property Rights) (opened for signature 15 April 1994, entered into force 1 January 1995) [TRIPS Agreement], art 27.

63 Patents Act, s 17.

64 Pfizer v Commissioner of Patents [2005] 1 NZLR 362 (CA) at [66].

65 Patents Act, s 2.

66 Pfizer, above n 64, at [58]; and Wellcome Foundation Ltd v Commissioner of Patents [1983] NZLR 385 (CA) at 391-392. 
suffering does not belong to the area of economic endeavour or trade and commerce". ${ }^{67}$ The "paramount aims of restoring health and decreasing pain" must take precedence over patent rights. ${ }^{68}$

However, this exemption is qualified. There are suggestions in New Zealand case law and IPONZ guidelines that non-surgical methods of human medical diagnosis are patentable. ${ }^{69}$ The Patents Bill 2008 will codify the common law position, excluding from patentability "methods of diagnosis practiced on humans". ${ }^{70}$ The phrase "practiced on humans" seems to exclude methods of diagnosis that are not performed directly on the human body. Methods of genetic diagnosis such as the BRCA tests performed by Myriad Genetics are non-surgical. They require a nurse or technician to take a swab from the patient's mouth, and diagnosis does not take place upon the patient's body, but separate to the patient in a laboratory.

This qualification to the exemption from patentability for medical methods has little authority. The case that has mentioned this qualification, Pharmaceutical Management Agency Ltd $v$ Commissioner of Patents, concerned 'Swiss' claims - patent applications for novel pharmaceutical uses of known substances - and not methods of treatment or diagnosis of humans. ${ }^{71}$ The comment in medical diagnosis the case is therefore obiter dicta. ${ }^{72}$ IPONZ guidelines, the other authority for the qualification, are non-binding outlines of how IPONZ approaches patent applications. ${ }^{73}$

Furthermore, it makes no sense to distinguish between diagnoses performed on the human body and diagnoses performed away from the human body. IPONZ justifies the distinction by saying that a diagnosis performed away from the human body is "an intellectual exercise", although that is not part of the test for an invention, or even for the later stages of inventive step or usefulness. ${ }^{74}$ Even if that were a valid contention, it is difficult to distinguish between what IPONZ considers an intellectual exercise and what it does not. The IPONZ guidelines describe unpatentable methods of diagnosis, performed on the human body: ${ }^{75}$

67 Wellcome, above $\mathrm{n} 66$, at 388 .

68 Pfizer, above n 64, at [116].

69 Pharmaceutical Management Agency Ltd v Commissioner of Patents [2000] 2 NZLR 529 (CA) [Pharmac] at [24]; and Intellectual Property Office of New Zealand "5.3 Medical treatment of humans" (Practice Guidelines, 2012).

70 Patents Bill 2008 (235-2), cl 15

71 Pharmac, above n 69, at [1].

72 At [24].

73 Bomac Research Ltd v Merial Ltd HC Wellington CIV-2009-485-2141, 14 April 2010 at [19].

74 IPONZ, above $\mathrm{n} 69$.

75 IPONZ, above n 69. 
Typically, the process of diagnosis involves a number of steps leading towards identification of a medical condition. Steps including data gathering, comparison of the data with normal values and recording any deviation, and finally attributing the deviation to a particular clinical picture would be considered to be a method of diagnosis of a disease or condition.

This process involves the researcher's intellectual and analytical skills in the same way that conducting a DNA test would. The process of gathering DNA samples, comparing the patient's DNA with normal DNA, and then diagnosing that patient with a genetic condition seems to fit perfectly into this definition. It is difficult to see how one method is more intellectual than the other. Furthermore, the rationale for limiting patentability in this area is that patents on methods of diagnosis would prevent doctors from giving their patients the best care. ${ }^{76}$ This rationale would apply equally to gene testing and other methods of diagnosis not performed on the human body.

IPONZ has accepted patent claims from Myriad Genetics, including a patent on the "MTS gene, mutations therein, and methods for diagnosing cancer using MTS gene sequence", ${ }^{77}$ and a patent over "Germline mutations in the MTS gene and method for detecting predisposition to cancer at the MTS gene". ${ }^{78}$ IPONZ currently allows gene patents, and methods of diagnosis involving genes. The rationale behind restricting patentability in the field of healthcare is that patents would make treatment and diagnosis less affordable and slow down research. The question is whether this rationale applies to isolated genes. To answer that question, we must consider the policy issues surrounding gene patents.

\section{POLICY ISSUES: RESEARCH, WHOLE-GENE SEQUENCING, HEALTHCARE COSTS AND MÄORI CONCERNS}

\section{$A$ The Effect of Gene Patents on Research}

The law in the area of gene patenting must take into account its effect on the field of biotechnology and, more importantly, its effect on the patients who receive gene-based treatment or diagnosis. The first question to consider is the effect of gene patents on research.

There are fears that allowing gene patents has created a "tragedy of the anticommons", where researchers face with a thicket of DNA patents, each one adding time and money to development. ${ }^{79}$ Some academics have argued that research happens despite these roadblocks; researchers seek out

76 Wellcome, above n 66, at 388; Pharmac, above n 69, at [29]; and Pfizer, above n 64, at [83]-[85].

77 Myriad Genetics "MTS gene, mutations therein, and methods for diagnosing cancer using MTS gene sequence" NZ Patent 283539, filed 17 March 1995, registered 12 June 1998.

78 Myriad Genetics "Germline mutations in the MTS gene and method for detecting predisposition to cancer at the MTS gene" NZ Patent 284612, filed 17 March 1995, registered 23 January 1998.

79 Myriad 1, above n 24, at 68-69. See also Michael Heller and Rebecca S Eisenberg "Can Patents Deter Innovation? The Anticommons in Biomedical Research" (1998) 280 Science 698. 
licenses to use genes in research, or find other ways to approach their research problem. ${ }^{80}$ In the Myriad case at first instance, expert witness Dr Fiona Murray concluded that the Myriad patents have negatively impacted the public knowledge of the BRCA genes by five-to- 10 per cent. ${ }^{81}$ It is also clear that patents and the related commercialisation of academic research raise the cost of research through licensing agreements and time delays. ${ }^{82}$ Papers and research are kept secret until they can yield patentable results, and the resulting atmosphere has a demoralising effect on scientists. ${ }^{83}$ The drive to patent also discourages scientists from publishing results, for fear of disclosing their invention and making it unpatentable. Dr David Ackerley thinks that a patent regime only minimally decreases academic secrecy in comparison to a regime of trade secrets. ${ }^{84}$ A counterargument is that patents are necessary to fund research and get initial private investment. ${ }^{85}$ Before analysing the truth of these competing claims, it is important to make some distinctions between different types of patents and different areas of medical research.

The more fundamental a product or method is to an academic field, the more likely it is to inhibit research. ${ }^{86}$ Human genes are the some of the most "fundamental building blocks of knowledge" in the biotechnological field. ${ }^{87}$ A patent on a gene is likely to inhibit research, because a researcher who works on or with that gene for any purpose risks infringing the patent. ${ }^{88}$ One solution to this problem would be to push patents downstream, so that rather than patenting the gene, the inventor patents a drug produced using the gene. ${ }^{89}$ Other researchers would still have

80 Sadao Nagaoka "An Empirical Analysis of Patenting and Licensing Practices of Research Tools from Three Perspectives" (paper presented at conference on research use of patented inventions, Madrid, May 2006). See also E Richard Gould and Bartha Maria Knoppers Biotechnology IP and Ethics (LexisNexis, Markham, Ontario, 2009) at 52.

81 Myriad 1, above n 24, at 70.

82 Gould and Knoppers, above n 80, at 135.

83 At $137-139$.

84 Email from Dr David Ackerley (Senior Lecturer in Biotechnology at Victoria University of Wellington) to Ruth Upperton (Author) regarding the effect of gene patents on research in New Zealand (8 August 2012).

85 Myriad 1, above n 24, at 78.

86 Helen M Berman and Rochelle Dreyfuss "Reflections on the Science and Law of Structural biology, Genomics, and Drug Development" (2005-2006) 53 UCLA L Rev 871 at 907.

87 Rochelle Dreyfuss "The Patentability of Genetic Diagnostics in US Law and Policy" (Public Law and Legal Theory Research Paper Series Working Paper No 10-68, NYU School of Law, 2010) at 28.

88 The effect of the research exemption in cl 136 of the Patents Bill 2008 is discussed in the final paragraph of Part IIIA of the article.

89 Berman and Dreyfuss, above n 86, at 907. See also CD Lopez-Beverage "Should Congress do something about upstream clogging caused by the deficient utility of expressed sequence tag patents?" (2005) $10 \mathrm{~J}$ Tech Law \& Policy 35. 
access to the gene, but not the drug that is generating money for the inventor. The only problem with this solution is that it does not help so much in the field of diagnostics, where the only products of research are often isolated genes and a method of comparing them with patients' genes. Both these results would be unpatentable, as both the gene and the process of comparing one DNA strand to another are too fundamental to the biotechnology sector to patent.

It is also important to distinguish between the effects of gene patenting on different areas of scientific research. ${ }^{90}$ Some biotechnology companies make therapeutic proteins. This field involves expensive research, development and testing. ${ }^{91}$ If patents were not available in this field, a company would be unlikely to recoup its research costs as other companies would be able to sell the same protein, driving down the cost. Furthermore, not allowing gene patents in this field might encourage companies to keep the details of their proteins as trade secrets. Therapeutic proteins are "incredibly difficult to reverse engineer" as they are very complicated molecules. ${ }^{92}$ Without the disclosure requirements under patent law, their structure could stay a secret forever. Patent law seems beneficial in this area.

Another area of biotechnology, one that Myriad Genetics is involved in, is developing genetic diagnostic methods. The cost of developing these methods in the United States is around USD 8,000 to 10,000 per sequence - much lower than the cost of developing therapeutic proteins. ${ }^{93}$ Furthermore, scientific curiosity and the desire to help patients, as well as government and patient group funding, act as incentives to the development of diagnostic tests. ${ }^{94}$ The patent system is not necessary in the diagnostic field, where research is cheaper than in the field of therapeutics.

Dr David Ackerley agrees that patent law, while necessary in the field of therapeutic proteins, is harmful in the area of diagnostics in New Zealand. ${ }^{95}$ Not only is it much cheaper to develop diagnostic tests, but furthermore, little invention goes into creating a diagnostic test through gene isolation. Dr Ackerley calls gene isolation "something many thousands of molecular biologists could do in their sleep" and does not think patent law should intrude in that area. ${ }^{96}$ Furthermore,

90 Abigail Lauer "The Disparate Effects of Gene Patents on Different Categories of Scientific Research" (2011) 25 Harv J Law and Tec 179.

91 At 185 .

92 At 187 .

93 At 188.

94 At 188 .

95 Email from Dr David Ackerley, above n 84.

96 Email from Dr David Ackerley, above n 84. 
New Zealand is a net importer of technology and intellectual property. ${ }^{97}$ Allowing gene patents might incentivise research, but that research is often happening overseas. Maybe one solution to these policy issues is to allow gene patents in the field of therapeutics, where the incentive of a patent is necessary, but not in the field of diagnostics, where patenting slows down research and drives up costs without providing any real benefits.

There have been several important studies on the effect of gene patents on research, which should be analysed with the above distinctions in mind. In 2003, Mildred K Cho conducted a survey of 122 United States' laboratory directors who provided DNA-based testing. ${ }^{98}$ Sixty-five per cent of those directors had been contacted about a patent infringement. ${ }^{99}$ Twenty-five per cent had stopped performing a test or service because of notification from a patent holder. ${ }^{100}$ Fifty-three per cent had decided not to develop or perform a test or service because of a patent. The BRCA patents were the most inhibiting; 7.3 per cent of all respondents had stopped performing the BRCA1 and BRCA2 tests because of Myriad's patents. ${ }^{101}$ Almost all laboratory directors thought patents had a negative effect on DNA-based testing services. ${ }^{102}$

Christopher M Holman has argued that the detrimental effect of patents is often overstated. ${ }^{103} \mathrm{~A}$ much-quoted figure is that 20 per cent of the human genome is patented in the United States. However, Holman points out that this figure is based on how many genes are mentioned in patent documents, not how many genes are actually patented. ${ }^{104}$

Less research has been done in New Zealand on the effect of gene patents on research. One study concluded that New Zealand "got the balance right" between encouraging innovation through gene patents and avoiding the negative effects of patents on development. ${ }^{105}$ The study surveyed

97 The Biotechnology Taskforce Growing the Biotechnology Sector in New Zealand: A Framework for Action (May 2003) at 44; and Cabinet Economic Development Committee Review of the Patents Act 1953 Stage 3: Part 1 (Ministry of Economic Development, 2002) at [13].

98 Mildred K Cho and others "Effects of Patents and Licenses on the Provision of Clinical Genetic Testing Services" (2003) 5(1) JMD 3.

99 At 5.

100 At 5 .

101 At 6 .

102 At 5 .

103 Christopher M Holman "Will Gene Patents Impede Whole Genome Sequencing? Deconstructing the Myth that 20 per cent of the Human Genome is Patented" (2012) 2(1) IP Theory 1.

104 At 2 .

105 Alphra Green "The Impact of Patents on New Zealand Genetic Services and Research Sectors" in Mark Heneghan (ed) Genes, Society and the Future (Brookers, Wellington, 2009) at 170. 
organisations that researched biotechnology or provided clinical genetic tests. ${ }^{106}$ Forty-five respondents from 30 different organisations replied, although the number of respondents answering each individual question varied. ${ }^{107}$ Half the research organisations that participated in the survey had abandoned licensing negotiations because of unrealistically high licensing fees, a failure to agree on terms, or because the organisation had found different technology to work with. ${ }^{108}$ Six out of fifteen respondents had not started a research project because of patents in that area, and four out of fourteen had abandoned projects halfway through due to patents. ${ }^{109}$ One big cost was the amount of time and money spent researching the patents in a given area before beginning research. ${ }^{110} \mathrm{~A}$ lot of respondents' concerns revolved around one Australian biotechnology company, Genetic Technologies Limited, which had exercised its patent rights aggressively in New Zealand from 2003 to $2005 .{ }^{111}$ This behaviour is in contrast to other overseas companies, which tend not to enforce or even file patents in New Zealand, because of our isolated position and small market size. ${ }^{12}$ The respondents were enthusiastic about owning patents themselves, but four out of six respondents who provided clinical genetic testing services thought that patents made tests more expensive for patients, and five out of six thought that patents increased the cost of genetic testing to laboratories. ${ }^{113}$

The survey had a low response rate, and also asked questions about a variety of gene-related patents without distinguishing between patents for isolated genes, method claims, and biomedical research tools. It is therefore difficult to conclude on the effect of patenting isolated genes in New Zealand. However, it seems that gene-related patents have caused relatively less harm here than in the United States. Patenting has driven up the cost of research and occasionally discourages research in over-patented areas, but it is also an important incentive for researchers. ${ }^{114}$ Overseas organisations are less likely to patent genes in New Zealand and subsequently defend those patent rights because of the relative unimportance of the New Zealand market.

One solution to patent law's sometimes detrimental effect on research would be to allow researchers to use patented subject matter for experimental purposes only. New Zealand does not

106 At 167.

107 At 168

108 At 172

109 At 176.

110 At 173

111 At $155-156$.

112 At 170 .

113 At 177-178.

114 At 164 
have a statutory research exemption. At common law experimental research using patents is permitted, but not research for commercial gain. ${ }^{115}$ The ultimate objective of the research determines whether it is experimental or commercial, and thus whether it is permitted or not. ${ }^{116}$ However, no New Zealand case has found that a use of a patent was experimental rather than infringing, and the scope of the exemption has become so narrow that it effectively has no application. ${ }^{117}$ The line between commercial and experimental research is often difficult to draw. This lack of clarity may be causing further problems, as researchers refrain from doing research that does not in fact infringe on the patent because they do not understand the law.

Under the Patents Bill, organisations will be able to "act for experimental purposes relating to the subject matter of an invention", which includes "seeking an improvement of the invention (for example, determining new properties, or new uses, of the invention)". ${ }^{118}$ The statutory exemption is broader than the common law exemption, allowing uses that might ultimately conflict with the exploitation of the patent, as long as the use has experimentation as its purpose. ${ }^{119}$ This exemption, if preserved in the final Act, will likely lessen patent law's detrimental effects on research.

\section{$B$ The Effect of Gene Patents on Whole-Gene Sequencing}

A related area of concern is the effect of gene patents on whole-gene sequencing. A person's genetics can determine what illnesses they suffer, as well as how those illnesses progress and react to treatment. ${ }^{120}$ If a doctor has a patient's genetic information, they can tailor treatment and prevention to suit that patient. Sequencing methods are becoming faster and cheaper; personalised medicine will soon be possible on a wide scale. However, to get a patient's genetic information it is necessary to sequence their genome. If the sequencing process involves isolating a patented gene, the sequencing would be in breach of that patent. For example, if a scientist were to sequence the whole genome of a person using traditional large-scale sequencing methods, they would be in breach of the BRCA patents if they isolated and sequenced those genes. In the Myriad appeal, Bryson $\mathrm{J}$ expressed his concern that broad genetic patents would have a chilling effect on wholegene sequencing. ${ }^{121}$

115 Smith Kline \& French Laboratories Ltd v Attorney-General [1991] 2 NZLR 560 (CA) at 566.

116 Ministry of Economic Development "A research exemption for the Patents Act: Progress report on policy work" (15 December 2004) RCP 1/7/2/5 at [25]-[27].

117 Susy Frankel "An Experimental use Exception for New Zealand" (2009) 17(5) JWIP 446 at 447-449.

118 Patents Bill, cl 136.

119 Frankel, above n 117, at 461.

120 W Nicholson Price II "Unblocked Future: Why Gene Patents Won't Hinder Whole-Genome Sequencing and Personalised Medicine" (2011) 33(4) CDZLR 1 at 2-3.

121 Myriad 2, above n 24, at 16-17. 
However, gene patents are not necessarily going to affect developments in the field of personalised medicine. New technology allows scientists to sequence DNA one chromosome at a time, without isolating any genes. ${ }^{122}$ This development means that a scientist could sequence an entire human genome, and not be in breach of any patents on isolated genes.

It is possible, therefore, to dismiss Bryson J's fear that granting a BRCA patent would slow the development of personalised medicine. The only patent that would inhibit this new technology would be a whole-chromosome or whole-genome patent. Moore J commented obiter dictum that chromosomes are not patentable. They are not markedly different from what is found in nature, and there are no current patents out on chromosomes, or settled expectations as to rights to chromosomes, that would necessitate allowing chromosome patents. ${ }^{123}$ At present most methods of whole-genome sequencing would potentially infringe patents in isolated genes. However, the future of whole-genome sequencing does not involve sequencing isolated genes, so patent law is unlikely to inhibit this exciting new area of genetic medicine.

\section{The Effect of Gene Patents on the Cost of Diagnosis}

A related policy issue is the effect of gene patents on the cost of and access to healthcare. Genetic Technologies, a Melbourne-based genetic testing business, owns patents over the BRCA patents in New Zealand and Australia, and in 2003 stated that it would not enforce its patent rights. ${ }^{124}$ However, in 2008, Genetic Technologies threatened legal action against eight laboratories which also provided BRCA tests in Australasia. ${ }^{125}$ The company later backed down in the face of public criticism, ${ }^{126}$ but the story is still illustrative of the potential dangers of gene patents. Patentholders that have not previously enforced their patent rights could do so at any time, and currently only public opinion might stop them.

In 2013, the cost of gene therapy and diagnosis in New Zealand varies. Genetic counseling using the Myriad Genetics BRCA tests is free to those with a 20 per cent chance of having a genetic predisposition to breast or ovarian cancer. ${ }^{127}$ This chance is calculated on the basis of family

122 See Andrew Pollack "Company Unveils DNA Sequencing Device Meant to Be Portable, Disposable and Cheap" The New York Times (online ed, New York, 17 February 2012).

123 Myriad 2, above n 24, at 19 per Moore J.

124 Genetic Technologies Group "Genetic Technologies to enforce rights to BRCA patents" (2008) Genetic Technologies <www.gtglabs.com.au>.

125 Genetic Technologies Group "Genetic Technologies to enforce rights to BRCA patents" (2008) Genetic Technologies <www.gtglabs.com.au>.

126 Genetic Technologies Group "New Position re BRCA testing" (2008) Genetic Technologies <www.gtglabs.com.au>.

127 "Breast cancer - Family history and genetic testing in New Zealand" (2009) The Breast Centre <www.thebreastcentre.co.nz>. 
history. Anyone else who wants to be tested may go to a private facility, where the cost is around NZD 2,000-3,000. ${ }^{128}$ The decision to fund genetic tests rests with each District Health Board; there is no advisory body that determines which genetic tests get funding, and the Laboratory Services Schedule, which lists which medical tests are publicly funded, does not include genetic tests. ${ }^{129}$

Most people in New Zealand who require a BRCA test can access it freely, and the owner of the BRCA patents in New Zealand is not currently enforcing those patent rights.

However, that owner does have a potential monopoly on a test that is very important to women's health. For an example of what could happen in the future, we need only to turn back to the United States, where Myriad Genetics has pursued an aggressive policy with regard to its BRCA patents. In North America, it generally provides the test itself, refusing to license other agencies to provide the test. Myriad Genetics began by offering a full test for USD 3,000; three days after the District Court ruling invalidating the BRCA patents, the cost was increased to over USD 4,000. ${ }^{130}$ Other organisations have offered the test to patients for USD 1,000-2,000, but have been stopped by Myriad Genetics' assertion of its patent rights. ${ }^{131}$ If any organisation with the right equipment could offer the test, prices would be much lower than they are at present, where Myriad Genetics has a monopoly.

In Canada, the government provided genetic testing for breast cancer using BRCA genes for CAD 1,200. Myriad Genetics requested licensing fees of CAD 3,850. Some provinces paid the fees, some ignored the request, and some have stopped providing the test altogether. ${ }^{132}$ Where Myriad provides the test itself, it charges a premium. Where it licenses out the right to provide the test, it charges huge licensing fees, the cost of which is passed on to the consumer.

Companies tend not to act as aggressively in New Zealand, because our small market size means any profit from licensing and patient fees will be tiny, compared to the United States or European markets. ${ }^{133}$ However, it would be dangerous for New Zealand to rely on this relative immunity; companies have enforced patent rights aggressively in the past, ${ }^{134}$ and they have the freedom to

128 "Breast cancer gene testing funded" (April 2011) 35 BPJ 50 at 51.

129 Imogen L Goold and others "Quality and safety of genetic testing in Australia and New Zealand: a review of the current regulatory framework" (2006) 3 ANZHP.

130 "Myriad raises price of BRCA testing, again" (19 April 2010) Yale Cancer Genetic Counseling <yalecancergeneticcounseling.blogspot.co.nz>.

131 Tom Reynolds "NCI-Myriad Agreement Offers BRCA Testing at Reduced Cost" (2000) 92 JNCI 596.

132 David Castle (ed) The Role of Intellectual Property Rights in Biotechnology Innovation (Edward Elgar, Cheltenham, 2009) at 76.

133 Green, above n 105, at 170.

134 At 155-156. 
enforce them again if they so choose. The Myriad Genetics experience in Canada and the United States is an illustration of what could happen in New Zealand without reform in the field of gene patenting. The cost of patenting may fall on our government rather than on individual New Zealanders, in the form of 'free' or subsidized healthcare, but the effect of patenting will still be harmful as patent fees cut into our nation's healthcare budget.

\section{Māori Concerns about Gene Patents}

A further policy issue is how to answer the Māori community's specific concerns about the patenting of genetic information. These concerns were canvassed in the Wai 262 Report. ${ }^{135}$ Allowing patents over the isolated genes of native plants and animals could undermine Treaty of Waitangi rights to Māori land, possessions and taonga. ${ }^{136}$ There are concerns that gene patents will override pre-existing Māori rights to New Zealand's biological resources. ${ }^{137}$ Intellectual property rights in genetic information could also undermine kaitiakitanga. ${ }^{138}$ If an individual gained a patent over the genes of species subject to kaitiakitanga, the kaitiaki might lose rights to the species, undermining the sacred relationship between kaitiaki and taonga species. The concerns expressed in the report are wide-ranging and many do not relate to gene patenting.

The Wai 262 report proposed a Māori committee to advise the Commissioner of Patents of an alleged invention's impact on Māori traditional knowledge and kaitiakitanga, and to share decisionmaking power with the Commissioner. ${ }^{139}$ The report also recommended forming a register of kaitiakitanga interests, as well as an ordre public exemption to allow the Commissioner to refuse a patent application if the alleged invention would unduly interfere with a kaitiakitanga relationship. ${ }^{140}$ The Patents Bill includes a public order exemption, so is more compatible with the Wai 262 recommendations than the current Act. ${ }^{141}$ Full disclosure requirements should compel an inventor to disclose their use of Māori traditional knowledge or taonga species in their invention. These reforms would in effect set up a sui generis regime for patents associated with Māori traditional knowledge and kaitiakitanga relationships. A sui generis regime is necessary because wider patent reform is unlikely to solve these issues. The issues surrounding indigenous intellectual

135 Wai 262 (Volume 1), above n 10.

136 Ministry of Economic Development Review of the Patents Act 1953: Boundaries to Patentability (Discussion Paper, March 2002) at 21-22.

137 Wai 262 (Volume 1), above n 10, at 178

138 An iwi or hapū's exercise of guardianship over land, native species and other taonga in their rohe (area). A kaitiaki is a person who acts as guardian over a particular taonga. For example, the Nelson-based iwi Ngāti Koata acts as kaitiaki over the tuatara.

139 Wai 262 (Volume 1), above n 10, at 210.

140 At 202

141 Patents Bill, cl 14. 
property go beyond the scope of this article, but it is important to note that all-purpose reform of our patent law will do little to solve the specific problems raised by the Wai 262 report.

\section{CONCLUSION}

New Zealand's current position on patenting isolated genes is in need of clarification. In its current state, our law has the potential to allow companies to hold genetic monopolies, tying up research, slowing down scientific progress, and increasing costs in the healthcare sector. A lot of the fears about gene patenting have not come to pass; we do not yet see a massive detrimental effect on research or on healthcare. However, these dangers are only kept at bay by the whim of overseas companies, which do not yet wish to assert their patent rights aggressively in our small market. ${ }^{142}$ We should reform our law before they change their minds. Furthermore, away from the field of policy, it is fundamentally inconsistent with the principles of patent law to allow patents on an isolated gene. An isolated gene is best classed as a discovery, not an invention, and generally should not have the benefit of patent protection.

Given my conclusion that isolated genes are not inventions, it would seem logical to argue for a Parliamentary clarification of that position in the Patents Bill. This solution would be TRIPScompliant, as TRIPS only requires that member states provide patent protection for inventions. ${ }^{143}$ However, a blanket exclusion from patentability is not a nuanced enough solution to this complex problem. Declaring that isolated genes are not inventions would make unpatentable isolated genes from non-human animals, as well as isolated genes in the field of therapeutic proteins. The first result is unwanted because the policy issues surrounding human gene patents are not the same as the issues surrounding animal gene patents. An animal's access to healthcare is not a moral issue and the commercialisation of animal health is already well underway. ${ }^{144}$ The second result is unwanted because patents in the field of therapeutic proteins are necessary given the costs of research and development in that area.

Luckily, there are more nuanced approaches available. In 2010, the United States' Secretary's Advisory Committee on Genetics, Health and Society recommended an exemption from patent infringement liability "for those who use patent-protected genes in the pursuit of research". ${ }^{145}$ It further recommended: ${ }^{146}$

142 Green, above n 105, at 170.

143 TRIPS Agreement, above n 62, art 27.1.

144 For example, New Zealand courts allow patents on methods of treatment of animals: Swift and Company $v$ Commissioner of Patents [1960] NZLR 775 (SC).

145 Dreyfuss, above n 87 , at 28.

146 At 27. 
The creation of an exemption from liability for infringement of patent claims on genes for anyone making, using, ordering, offering for sale, or selling a test developed under the patent for patient care purposes.

Once the Patents Bill 2008 becomes law, New Zealand will have a strong research exemption. ${ }^{147}$ The Committee's second recommendation should also become part of New Zealand law. It would allow organisations to provide diagnostic testing without having to pay licensing fees. ${ }^{148}$ Researchers in the field of diagnostics would be free to research according to their skills and the needs of society, not according to which genes are free to work on. This solution would push patents in the field of gene diagnostics downstream, freeing up more of the fundamental tools researchers need to provide better services for patients. Holders of patents on isolated genes would be unable to assert their rights in respect of diagnostic tests. Holders of patents on isolated genes would be able to assert their rights in the field of therapeutics, where the incentive of patent rights is necessary.

This solution would be TRIPS-compliant, as TRIPS allows member states to make unpatentable "diagnostic, therapeutic and surgical methods for the treatment of humans or animals, plants and animals". ${ }^{149}$ The exemption would be an extension of the current exemption from patentability for methods of medical diagnosis and treatment, ${ }^{150}$ which logically should be extended to cover diagnosis that does not take place on the human body anyway.

It is necessary to put this exemption in statute, as a court would be unlikely to distinguish on the grounds of policy between a therapeutic and a diagnostic use of a gene, and instead create a blanket rule allowing or not allowing all gene patents. Although refusing all gene patents on the ground that they are not inventions would be legally appropriate, it would not be good policy to do so.

Gene patenting has not yet caused any major problems in New Zealand. ${ }^{151}$ However, biotechnology is a growing sector, in New Zealand and around the world. ${ }^{152}$ As the sector grows, the issues of who owns what and how they can assert their rights will become more and more pressing, and as our dependence on genetic medicine grows, so too will the dangers inherent in allowing private companies monopolies in this area. Parliament should act now to remove from the commercial realm isolated human genes used in the field of diagnostics.

147 Patents Bill, cl 136.

148 Dreyfuss, above $\mathrm{n} 87$, at 27.

149 TRIPS Agreement, above n 62, art 27.3.

150 Pharmac, above n 69, at [24]; IPONZ, above n 69; and Patents Bill, cl 15.

151 See Green, above n 105.

152 New Zealand Trade and Enterprise "Biotechnology and Agricultural Technology" <www.nzte. govt.nz>. 
